\title{
HERMITE INTERPOLATION OF COMPOSITION FUNCTION AND STEFFENSEN-TYPE INEQUALITIES
}

\author{
ASFAND FAHAD, JOSIP PEČARIĆ AND MARJAN PRALJAK
}

Abstract. Hermite interpolation of composition function and some related inequalities are given. The obtained inequalities are closely related to a generalization of Steffensen's inequality given by the current authors in [2].

Mathematics subject classification (2010): 26D10, 26D15.

Keywords and phrases: Steffensen's inequality, Faà di Bruno's formula.

\section{REFERENCES}

[1] P. Agarwal, Y. Wong, Error Inequalities in Polynomial Interpolation and Their Applications, Kluwer Academic Publisher, 1993.

[2] A. FAhad, J. PeČArić, M. PraljaK, Generalized Steffensen's inequality, J. Math. Ineq. 9 (2015), no. 2, 481-487.

[3] E. Hewitt and K. Stromberg, Real and abstract analysis, 3rd edition, Springer, New York, 1975.

[4] J. PEČARIĆ, Connections among some inequalities of Gauss, Steffensen and Ostrowski, Southeast Asian Bull. Math. 13 (1989), no. 2, 89-91.

[5] J. PeČarić, F. Proschan and Y. L. Tong, Convex functions, Partial Orderings and Statistical Applications, Academic Press, New York, 1992.

[6] P. RABIER, Steffensen's inequality and $L^{1}-L^{\infty}$ estimates of weighted integrals, Proc. Amer. Math. Soc. 140 (2012), no. 2, 665-675.

[7] J. F. STEFFENSEN, On certain inequalities between mean values, and their application to actuarial problems, Skand. Aktuarietidskr. 1 (1918), 82-97. 